\title{
Dietary Supplement of Tumeric (Curcuma longa) Powder: Impact on Haematological and Biochemical Responses in Clarias gariepinus (Burchell, 1822) Fingerlings
}

\author{
Afamdi Anene ${ }^{1}$, Eme Okories Okorie ${ }^{1}$, Malachy N. O. Ajima ${ }^{2, *}$, Janet Onyemaonwu ${ }^{1}$ \\ ${ }^{1}$ Animal Nutrition Laboratory, Department of Animal Science and Fisheries, Faculty of Agriculture, Abia State \\ University, Umuahia Campus, Abia State, Nigeria. \\ ${ }^{2}$ Department of Fisheries and Aquaculture Technology, Federal University of Technology, Owerri, Nigeria.
}

\section{How to cite}

Anene, A., Okorie, E.O., Ajima, M.N.O., Onyemaonwu, J. (2022). Dietary Supplement of Tumeric (Curcuma longa) Powder: Impact on Haematological and Biochemical Responses in Clarias gariepinus (Burchell, 1822) Fingerlings. Aquaculture Studies, 22(2), AQUAST714. http://doi.org/10.4194/AQUAST714

\section{Article History}

Received 11 July 2021

Accepted 12 October 2021

First Online 14 October 2021

\section{Corresponding Author}

Tel.: +2348030896255

E-mail: malajimo@gmail.com

\section{Keywords}

Blood indexes

Fish

Diet

Enzymes

Immunity

\begin{abstract}
Dietary supplementation with herbal extract in the diet of fish has been noted to increase aquaculture production through the improvement of immunity and other physiological dysfunctions related to fish health. A feeding trial was conducted to assess the impact of incorporating varied concentrations of turmeric powder (TP) on haematological and biochemical responses in Clarias gariepinus fingerlings. Five test diets were composed as $\mathrm{T}_{1}$ ((control) (basal diet $\left.+0 \% \mathrm{TP}\right)$ ), $\mathrm{T}_{2}$ (basal diet $\left.+1 \% \mathrm{TP}\right), \mathrm{T}_{3}$ (basal diet $+2 \% \mathrm{TP}$ ), $\mathrm{T}_{4}$ (basal diet $+3 \% \mathrm{TP}$ ) and $\mathrm{T}_{5}$ (basal diet $+4 \% \mathrm{TP}$ ). Fish specimens were apportioned into five groups in triplicate. Significantly lower $(P<0.05)$ red blood cell count was found in those fed control diet compared with the other inclusion. Highest values of white blood cell count were noticed in T5 when compared with the control. There were significant differences in haemoglobin between T1 and T5. Highest values of serum glutamic pyruvic transaminase, serum glutamic oxaloacetic transaminase, glucose and cholesterol level were found in $\mathrm{T} 2$ when compared with the control. TP can be used as feed supplement in the diet of $C$. gariepinus without any adverse effect on physiological responses of the fish.
\end{abstract}

\section{Introduction}

Aquaculture constituents a major segment of the animal production enterprises, due to the sustained advancement in culturing fishes and shellfish species and arguably the fastest growing industry with an annual production capacity of 800 million tonnes (Kolkovski and Kolkovski, 2011).

Nigeria is among the highest aquaculture production in sub Saharan African with an output of 21700 tonnes in 1999 to 316700 tonnes in 2015. Among other fishes, catfish is the most important cultured fish species that are usually grown in ponds and tanks; and constitutes more than half of the total aquaculture production in Nigeria.
The culture and production of the fish species may have greeted with high incidence mortality, high stressrelated diseases, suppressed immune system and other physiological dysfunctions due to bacterial infections. Many types of antibiotics including oxytetracycline, chloramphenicol, sulfonamides and other anthelmintic agents have been applied to overcome or subdue bacterial infections in aquaculture production (Sahu et al., 2005: Fawole et al., 2016). Unfortunately, the continuous introduction of these drugs in fish production has resulted to the development of residual effects and resistivity risk to livestock as well as human health (Magrone et al., 2016, Arciuli et al., 2017). However, in order to ameliorate or overcome the ugly development, attention is being given to the use or 
production of alternative medicinal plant or phytogenic as feed supplement in aquaculture practices which are potent in mitigating the impasse of diseases by increasing the immune system of fish (Fawole et al., 2020; Iheanacho et al., 2018).

Medicinal plants or phytogenic feed supplement are made up bioactive ingredients and also possesses antimicrobial and antioxidative properties that are usually incorporated in animals' diets in order to improve their performances (Yang et al., 2015; Landy et al., 2011).

Many studies have reported the incorporation of different plant supplements or additives to improve the physiological dysfunctions of fish (Xia et al., 2015; Sanchez et al., 2019; Dewi et al., 2020; Fawole et al., 2020).

Among the plants used as dietary supplements in aquaculture production, turmeric (Curcuma longa) is a herbaceous plant of ginger which belongs to family Zingiberaceae. It constitutes numerous substances including curcumin, artumerone and zingiberene that possess antioxidant properties (Ruby et al. 1995; Chan et al. 2009). Studies have shown that turmeric produces great variety of pharmaceutical potential including antitoxic, antiturmor, hepatoprotective, immunomudulatory and antibacterial agents in biological systems (Tayyem et al., 2006; Prasad and Aggarwal, 2011; Arulkumar et al., 2017). Aqueous as well as ethanolic components of turmeric could be important treatment against bacterial diseases in aquaculture production (Sahu et al., 2005). Supplementation of turmeric in diet of Oreochromis niloticus, improved growth performance and protected the fish against Pseudomonas fluorescens infection (Mahmoud et al., 2014) and elevated the nonspecific immune system and protected fish against Aeromonas hydrophila infection (Sahu et al., 2008). Apart from fish, Daneshyar et al. (2011) reported that inclusion of turmeric powder in broiler chickens feed could improve the quality of the meat by reducing its saturated fatty acids and triglycerides concentration.

Blood and biochemical indexes are important tools used in to evaluate the nutritional and health status of fish in reaction to different diets (Jahanbakhshi et al., 2013). The information on the dietary supplementation of turmeric powder in the diet on the physiological responses of $C$. gariepinus is scanty. The study was planned to find out the haematological and biochemical reactions in $C$. gariepinus fed diet incorporated with varied levels of turmeric powder.

\section{Materials and Methods}

\section{Collection of Turmeric Plant and Preparation}

Fresh rhizome of turmeric plant, ginger ( $C$. longa) was procured from National Root and Crops Institute Research Umudike, Abia State Nigeria. It was washed, cooked and sun dried in a shade. The dried rhizome was ground into fine powder using machine, sieved, using appropriate mesh size, packed in tight container and kept at room temperature till further use.

\section{Experimental Diet}

Five experimental diets were formulated as $T_{1}$ ((Control) (basal diet + $0 \% \mathrm{TP})$ ), $\mathrm{T}_{2}$ (basal diet $\left.+1 \% \mathrm{TP}\right)$, $\mathrm{T}_{3}$ (basal diet $+2 \% \mathrm{TP}$ ), $\mathrm{T}_{4}$ (basal diet $+3 \% \mathrm{TP}$ ) and $\mathrm{T}_{5}$ (basal diet $+4 \%$ TP). The ingredient presented in Table 1 was used for the formulation of the diet. They were weighed accordingly based on the proportion of each diet. The diet was stirred extensively, water was included, and the diet was made into pellets using machine. The pelleted diet was dried, packed in tight polyethene bag and preserved for further use.

As presented in Table 1, proximate composition of the feed was done according to AOAC (2005).

Table 1. Ingredients and proximate composition of experimental diet.

\begin{tabular}{|c|c|c|c|c|c|}
\hline \multirow[b]{2}{*}{ Ingredients (\%) } & \multicolumn{5}{|c|}{ Treatment \% } \\
\hline & $\mathrm{T}_{1}$ & $\mathrm{~T}_{2}$ & $\mathrm{~T}_{3}$ & $\mathrm{~T}_{4}$ & $\mathrm{~T}_{5}$ \\
\hline Maize Grain & 49.80 & 49.80 & 49.80 & 49.80 & 48.80 \\
\hline Soy Bean & 27.50 & 26.50 & 26.50 & 26.50 & 27.50 \\
\hline Wheat Offal & 12.00 & 11.50 & 11.00 & 10.0 & 9.0 \\
\hline Palm kernel Cake & 5.10 & 5.10 & 5.10 & 5.10 & 5.10 \\
\hline Fish Meal & 3.00 & 3.00 & 3.00 & 3.00 & 3.00 \\
\hline Bone Meal & 1.00 & 1.00 & 1.00 & 1.00 & 1.00 \\
\hline Vitamin Premix & 0.25 & 0.25 & 0.25 & 0.25 & 0.25 \\
\hline Methionine & 0.10 & 0.10 & 0.10 & 0.10 & 0.10 \\
\hline Salt & 0.25 & 0.25 & 0.25 & 0.25 & 0.25 \\
\hline Palm Oil & 1.00 & 1.00 & 1.00 & 1.00 & 1.00 \\
\hline Turmeric Powder & 0.00 & 1.0 & 2.0 & 3.0 & 4.0 \\
\hline Total & 100 & 100 & 100 & 100 & 100 \\
\hline \multicolumn{6}{|c|}{ Proximate composition (\%) } \\
\hline Protein & $30.42 \pm 1.36$ & $32.57 \pm 2.64$ & $31.13 \pm 1.18$ & $30.76 \pm 1.71$ & $31.27 \pm 1.23$ \\
\hline Fat & $7.90 \pm 0.18$ & $8.42 \pm 0.32$ & $8.21 \pm 0.25$ & $7.82 \pm 0.87$ & $9.19 \pm 0.17$ \\
\hline Moisture & $11.48 \pm 0.52$ & $12.24 \pm 0.20$ & $12.07 \pm 0.12$ & $11.80 \pm 0.83$ & $11.69 \pm 0.72$ \\
\hline Ash & $9.42 \pm 0.40$ & $9.61 \pm 0.65$ & $9.78 \pm 0.71$ & $10.39 \pm 0.32$ & $10.18 \pm 1.23$ \\
\hline Fibre & $7.71 \pm 0.76$ & $7.85 \pm 0.81$ & $7.92 \pm 1.90$ & $8.20 \pm 1.23$ & $8.34 \pm 0.30$ \\
\hline
\end{tabular}




\section{Fish and Feeding Experiment}

Clarias gariepinus $(n=180$, mean weight $5.14 \pm 0.13$ g) procured from a fish farm in Umuahia Abia State was used for the study. The fish were transported in oxygen bags to Animal Science and Fisheries Laboratory, Abia State University, Uturu and held in a tank containing 500 $\mathrm{L}$ of dechlorinated tap water. Prior to feeding experiment, the fish were acclimatized for two weeks and were fed with commercial feed.

The fish were not fed 24 hours before the commencement of the study. They were randomly distributed into five experimental groups and stocked with fifteen fish per tank of $150 \mathrm{~L}$ capacity in triplicate for each treatment group and filled with $80 \%$ capacity of dechlorinated tap water. The fish were fed two times daily to satiation at 9:00 and 16:00 hrs. Water in each experimental tank was renewed every three days while the debris of uneaten feed was siphoned daily to disallow pollution of the tanks and the water replaced thereupon. Continuous ventilation was made available to all the experimental tanks. The investigation was carried out indoors under natural photoperiod of 12:12 light-dark cycle. Physicochemical parameters such as temperature, $\mathrm{pH}$, dissolved oxygen, alkalinity, total hardness and free carbon (iv) oxide were analysed according to APHA (2005) and were maintained within the range as: temperature $\left(27.50-28.50^{\circ} \mathrm{C}\right), \mathrm{pH}(6.8-$ 7.6), dissolved oxygen (6.50-7.35 $\left.\mathrm{mg} \mathrm{L}^{-1}\right)$, alkalinity (15.81-18.22 $\left.\mathrm{mg} \mathrm{L}^{-1}\right)$, total hardness (228-238 $\left.\mathrm{mg} \mathrm{L}^{-1}\right)$, free carbon (iv) oxide (4.13 $\left.-4.28 \mathrm{mg} \mathrm{L}^{-1}\right)$. At the end of the feeding trial which lasted for 60 days, the fish were sampled for haematological and biochemical analysis.

\section{Haematological Analysis}

Feeding of the fish was stopped $24 \mathrm{hr}$ before sampling. Before blood collection, fish were anesthetized with MS 222 in order to reduce stress. Heparinized plastic syringe rinsed with $10 \%$ ethylene diaminetetraacetic acid (EDTA solution) was used to collect blood from the fish ( 4 fish per tank, $n=12$ per experimental group) through the caudal vein. The blood was stored in eppendroff tube rinsed with EDTA and later used to estimate red blood cell (RBC), white blood cell (WBC) packed cell volume (PCV) and haemoglobin $(\mathrm{Hb})$. RBC and WBC expressed in cubic millimeter were analysed using Neubauer-type hemocytometer according to Rusia and Sood (1992).

$\mathrm{Hb}$ level of blood was estimated following the cyanmethemoglobin method according to Blaxhall and Daisely (1973). Briefly, $0.02 \mathrm{~mL}$ specimen of blood was stirred with $4 \mathrm{~mL}$ Drabkin's solution and left to stay for $10 \mathrm{~min}$ for appropriate development of colour due to absorbance which was read at $540 \mathrm{~nm}$ by Unican spectrophotometer against a blank. PCV was analyzed in heparinized glass capillaries after centrifugation in a microhematocrit centrifuge according to Nelson and Morris (1989). Eosinophils, neutrophils, monocytes, lymphocytes, and basophils in the blood were estimated according to Anderson (2003). Mean corpuscular volume (MCV), mean corpuscular haemoglobin $(\mathrm{MCH})$ and mean corpuscular haemoglobin concentration $(\mathrm{MCHC})$ were calculated using the formulae:

$$
\begin{gathered}
\operatorname{MCV}(\mathrm{FL})=\frac{\text { Haematocrit }(\%) \mathrm{X} 10}{\mathrm{RBC}\left(10^{12} / \mathrm{L}\right.} \\
\operatorname{MCH}(\mathrm{pg})=\frac{\left(\frac{\mathrm{g}}{\mathrm{dL}}\right) \times 10}{\mathrm{RBC}\left(\times 10^{12} / \mathrm{L}\right.} \\
\operatorname{MCHC}\left(\frac{\mathrm{g}}{\mathrm{dL}}\right)=\frac{H b\left(\frac{g}{L}\right)}{\text { Haematocrit }} \times 100
\end{gathered}
$$

\section{Biochemical Analysis}

Fresh fish blood was collected with syringe from another batches of 4 fish per tank ( $n=12$ per experimental group) and then poured into a dried Eppendorf tube to allow for the clotting of the blood. The samples were centrifuged at 3,000 rpm for 10 mins at $4^{\circ} \mathrm{C}$ to get the serum.

Glucose level was determined using O-toluidine method (Cooper and MacDaniel, 1970). Total protein was estimated spectrophotometrically according to Bradford (1976). Serum glutamic pyruvic transaminase (SGPT/ALT) and serum glutamic oxaloacetic transaminase (SGOT/AST) were determined following Reitman and Frankel (1957). Alkaline phosphatase (ALP) was determined according to Essey et al. (1946). Creatinine was determined according to Henry et al. (1974). Urea was assessed according to Coulombe and Favreau (1963) while cholesterol was determined according to Allain et al. (1974).

\section{Statistical Analysis}

Data are presented as mean \pm standard error. Statistical package SPSS 20.0 computer program was used to evaluate the data. One-way analysis of variance was used to determine the variation among treatments and the reference, followed by Post hoc test using Duncan multiple tests at $5 \%$ level of significance.

\section{Results}

\section{Haematological Responses}

The results of blood parameters of $C$. gariepinus fed diet incorporated with varying levels of turmeric powder as presented in Table 2 revealed no significant difference $(P>0.05)$ in those fish fed control diet $(\mathrm{T} 1)$ and among the treatment groups. WBC in the T5 which contained the inclusion level ( $4 \%$ turmeric) was highest, followed by $T_{4}, T_{3}, T_{2}$ and $T_{1}$ (Control diet).

A significant difference $(P<0.05)$ existed between the treatments and the control. Haemoglobin was 
highest in the fish fed diet $\mathrm{T}_{2}$ (1\% turmeric) compared with the other inclusion levels and was significant $(P<0.05)$ when compared with the control diet. Treatment containing $0 \%$ turmeric powder $\left(T_{1}\right.$, control diet) inclusion had the highest value of haematocrit while $T_{5}$ containing ( $4 \%$ turmeric powder) inclusion had the lowest value. The values indicated no significant difference $(P>0.05)$ among the treatments groups and the control. The results of both $\mathrm{MCV}$ and $\mathrm{MCH}$ of the fish showed that $\mathrm{T}_{2}$ which contained $1 \%$ turmeric powder inclusion had the highest values of 57.85 and 18.52 respectively and was found to be significant $(P<0.05)$ when compared with other treatments and the control diet. Highest value of $\mathrm{MCHC}$ was recorded in $\mathrm{T}_{2}$ followed by control which was not significant $(P>0.05)$ when compared with other treatments.

The results of white blood cell component including lymphocytes, monocytes, neutrophils, eosinphils and basophils as shown in Table 3 indicated no significant difference $(P>0.05)$ in all the indexes tested between the fish fed varying levels of turmeric powder and the control, depleting that the diet can be included in their feed at the following inclusion levels ( $0 \%, 1 \%, 2 \%, 3 \%$ and $4 \%)$ without affecting their white blood cell components.

\section{Biochemical Parameters}

The value of blood sugar as presented in Table 4 showed a decreasing tread from $\mathrm{T}_{1}$ to $\mathrm{T}_{5}$. Treatment means $\mathrm{T}_{1}, \mathrm{~T}_{2}$ and $\mathrm{T}_{3}$ containing the inclusion levels of $0 \%$, $1 \%$ and $2 \%$ respectively had significant difference $(P<0.05)$ when compared with $\mathrm{T}_{4}(3 \%$ of $\mathrm{TP})$ and $\mathrm{T}_{5}(4 \%$ of TP) inclusion levels. A significant $(P<0.05)$ lowest value $(68.10 \mathrm{mg} / \mathrm{dl})$ of cholesterol was found in $T_{2}$ containing inclusion level of $1 \%$ turmeric powder when compared with the control that had the highest value $(83.40 \mathrm{mg} / \mathrm{dl})$ of cholesterol. The highest value of urea was recorded in control diet which was not significant $(P>0.05)$ when compared with other treatments while there was no significant difference $(P>0.05)$ in value of creatinine in the fish fed both the varying levels of turmeric power and the control. There was a significant $(P<0.05)$ reduction in the levels of serum glutamic

Table 2. Mean $\pm(\mathrm{SE})$ values of haematological parameters of $C$. gariepinus fingerlings fed diets incorporated with Turmeric powder.

\begin{tabular}{lccccc}
\hline \multicolumn{5}{c}{ Treatments } \\
\hline Parameters & $\mathrm{T}_{1} 0 \%(\mathrm{TP})$ & $\mathrm{T}_{2} 1 \%(\mathrm{TP})$ & $\mathrm{T}_{3} 2 \%(\mathrm{TP})$ & $\mathrm{T}_{4} 3 \%(\mathrm{TP})$ & $\mathrm{T}_{5} 4 \%(\mathrm{TP})$ \\
\hline RBC $\left(\mathrm{x} 10^{12} / \mathrm{L}\right)$ & $5.73 \pm 0.35^{\mathrm{a}}$ & $5.30 \pm 0.15^{\mathrm{a}}$ & $5.87 \pm 0.29^{\mathrm{a}}$ & $5.97 \pm 0.29^{\mathrm{a}}$ & $5.47 \pm 0.18^{\mathrm{b}}$ \\
WBC $\left(10^{9} / \mathrm{L}\right)$ & $13.03 \pm 0.02^{\mathrm{a}}$ & $16.67 \mathrm{~b} \pm 0.13^{\mathrm{b}}$ & $16.63 \pm-0.75^{\mathrm{b}}$ & $16.27 \pm 1.44^{\mathrm{b}}$ & $16.70 \pm 0.55^{\mathrm{b}}$ \\
Haemoglobin $(\mathrm{g} / \mathrm{dL})$ & $6.83 \pm 0.76^{\mathrm{a}}$ & $10.10 \pm 0.15^{\mathrm{b}}$ & $8.73 \pm 0.48^{\mathrm{c}}$ & $8.23 \pm 0.19^{\mathrm{c}}$ & $8.60 \pm 0.23^{\mathrm{c}}$ \\
Haematocrit $(\%)$ & $30.07 \pm 0.99^{\mathrm{a}}$ & $30.00 \pm 0.58^{\mathrm{a}}$ & $29.47 \pm 1.57^{\mathrm{a}}$ & $30.93 \pm 0.41^{\mathrm{a}}$ & $29.17 \pm 0.76^{\mathrm{a}}$ \\
MCV (FL) & $46.13 \pm 1.67^{\mathrm{b}}$ & $57.85 \pm 2.72^{\mathrm{a}}$ & $46.88 \pm 3.04^{\mathrm{b}}$ & $43.73 \pm 2.78^{\mathrm{b}}$ & $38.78 \pm 1.69^{\mathrm{b}}$ \\
MCH (pg) & $15.07 \pm 0.65^{\mathrm{b}}$ & $18.52 \pm 0.96^{\mathrm{a}}$ & $14.91 \pm 0.93^{\mathrm{b}}$ & $13.89 \pm 0.96^{\mathrm{c}}$ & $13.51 \pm 0.60^{\mathrm{c}}$ \\
MCHC (g/dL) & $32.65 \pm 0.57^{\mathrm{a}}$ & $32.99 \pm 0.16^{\mathrm{a}}$ & $31.80 \pm 0.06^{\mathrm{a}}$ & $31.74 \pm 0.24^{\mathrm{a}}$ & $32.26 \pm 0.38^{\mathrm{a}}$ \\
\hline
\end{tabular}

$\mathrm{RBC}=$ Red blood cell, $\mathrm{WBC}=$ White blood cell, $\mathrm{MCV}=$ mean corpuscular volume, $\mathrm{MCH}=$ mean corpuscular haemoglobin, $\mathrm{MCHC}=$ mean corpuscular haemoglobin concentration Mean values with different letter superscripts along the rows differ significantly $(P<0.05), n=15$

Table 3. Mean \pm (SE) values of differential WBC counts (\%) in C. gariepinus fingerlings fed diet incorporated with Turmeric powder.

\begin{tabular}{llllll}
\hline \multicolumn{5}{c}{ Treatments } \\
\hline Parameters & $\mathrm{T}_{1} 0 \%(\mathrm{TP})$ & $\mathrm{T}_{2} 1 \%(\mathrm{TP})$ & $\mathrm{T}_{3} 2 \%(\mathrm{TP})$ & $\mathrm{T}_{4} 3 \%(\mathrm{TP})$ & $\mathrm{T}$ ) \\
\hline Lymphocytes & $2.28 \pm 0.21^{\mathrm{a}}$ & $2.80 \pm 0.89^{\mathrm{a}}$ & $2.37 \pm 0.82^{\mathrm{a}}$ & $2.43 \pm 0.09^{\mathrm{a}}$ & $2.30 \pm 0.76^{\mathrm{a}}$ \\
Monocytes & $1.80 \pm 0.06^{\mathrm{a}}$ & $1.93 \pm 0.09^{\mathrm{a}}$ & $2.47 \pm 0.26^{\mathrm{a}}$ & $2.40 \pm 0.43^{\mathrm{a}}$ & $2.83 \pm 0.33^{\mathrm{a}}$ \\
Neutrophil & $8.15 \pm 0.09^{\mathrm{a}}$ & $8.33 \pm 0.54^{\mathrm{a}}$ & $8.10 \pm 0.86^{\mathrm{a}}$ & $8.27 \pm 0.90^{\mathrm{a}}$ & $8.17 \pm 0.33^{\mathrm{a}}$ \\
Eosinophil & $1.37 \pm 0.09^{\mathrm{a}}$ & $1.53 \pm 0.05^{\mathrm{a}}$ & $1.33 \pm 0.16^{\mathrm{a}}$ & $1.37 \pm 0.33^{\mathrm{a}}$ & $1.23 \pm 0.03^{\mathrm{a}}$ \\
Basophils & $0.80 \pm 0.56^{\mathrm{a}}$ & $1.00 \pm 0.12^{\mathrm{a}}$ & $0.97 \pm 0.09^{\mathrm{a}}$ & $0.80 \pm 0.06^{\mathrm{a}}$ & $0.90 \pm 0.06^{\mathrm{a}}$ \\
\hline
\end{tabular}

Table 4. Mean $\pm(\mathrm{SE})$ values of serum biochemistry in C. gariepinus fingerlings fed diets incorporated with Turmeric powder

\begin{tabular}{lccccc}
\hline \multicolumn{5}{c}{ Treatments } \\
\hline Parameters & $\mathrm{T}_{1} 0 \%(\mathrm{TP})$ & $\mathrm{T}_{2} 1 \%(\mathrm{TP})$ & $\mathrm{T}_{3} 2 \%(\mathrm{TP})$ & $\mathrm{T}_{4} 3 \%(\mathrm{TP})$ & $\mathrm{T}_{5} 4 \%(\mathrm{TP})$ \\
\hline Blood sugar (mg/dl) & $72.73 \pm 0.64^{\mathrm{a}}$ & $71.47 \pm 1.41^{\mathrm{a}}$ & $70.97 \pm 1.17^{\mathrm{a}}$ & $66.40 \pm 1.30^{\mathrm{b}}$ & $60.40 \pm 1.36^{\mathrm{c}}$ \\
Cholesterol & $81.40 \pm 0.62^{\mathrm{c}}$ & $72.10 \pm 0.12^{\mathrm{a}}$ & $78.30 \pm 1.13^{\mathrm{b}}$ & $78.27 \pm 1.13^{\mathrm{b}}$ & $76.53 \pm 0.92^{\mathrm{b}}$ \\
Urea (mg/dl) & $12.53 \pm 0.12^{\mathrm{a}}$ & $12.23 \pm 0.29^{\mathrm{a}}$ & $13.03 \pm 0.84^{\mathrm{a}}$ & $12.80 \pm 0.15^{\mathrm{a}}$ & $12.80 \pm 0.42^{\mathrm{a}}$ \\
Creatinine (mg/dl) & $0.13 \pm 0.05^{\mathrm{a}}$ & $0.12 \pm 0.04^{\mathrm{a}}$ & $0.13 \pm 0.03^{\mathrm{a}}$ & $0.14 \pm 0.03^{\mathrm{a}}$ & $0.13 \pm 0.02^{\mathrm{a}}$ \\
SGPT /ALT (U/I) & $53.30 \pm 0.91^{\mathrm{a}}$ & $42.47 \pm 6.86^{\mathrm{c}}$ & $44.53 \pm 6.65^{\mathrm{b}}$ & $45.50 \pm 9.72^{\mathrm{b}}$ & $52.43 \pm 3.32^{\mathrm{a}}$ \\
SGOT /AST (U/l) & $61.32 \pm 0.62^{\mathrm{a}}$ & $50.48 \pm 5.16^{\mathrm{c}}$ & $46.22 \pm 6.65^{\mathrm{d}}$ & $55.53 \pm 3.11^{\mathrm{b}}$ & $62.43 \pm 0.18^{\mathrm{a}}$ \\
ALP (U/I) & $56.27 \pm 0.98^{\mathrm{a}}$ & $54.33 \pm 6.86^{\mathrm{a}}$ & $56.53 \pm 6.65^{\mathrm{a}}$ & $55.50 \pm 9.72^{\mathrm{a}}$ & $57.43 \pm 3.32^{\mathrm{a}}$ \\
Glucose (mg/dl) & $23.77 \pm 1.31^{\mathrm{b}}$ & $28.87 \pm 0.84^{\mathrm{a}}$ & $27.80 \pm 0.87^{\mathrm{a}}$ & $26.83 \pm 0.58^{\mathrm{a}}$ & $24.77 \pm 0.18^{\mathrm{b}}$ \\
Total protein (mg/dl) & $7.27 \pm 0.15^{\mathrm{a}}$ & $7.42 \pm 0.05^{\mathrm{a}}$ & $7.33 \pm 0.22^{\mathrm{a}}$ & $7.36 \pm 0.38^{\mathrm{a}}$ & $7.43 \pm 0.09^{\mathrm{a}}$ \\
\hline SGPT/ALT Seum
\end{tabular}

SGPT/ALT = Serum glutamic pyruvic transaminase, SGOT/AST = Serum glutamic oxaloacetic transaminase, ALP = Alkaline phosphatase. Mean values with different letter superscripts along the rows differ significantly $(P<0.05), n=15$ 
pyruvic transaminase (SGPT/ALT) and serum glutamic oxaloacetic transaminase (SGOT/AST) in the fish fed $T_{2}$ in comparison with the control. The activities of alkaline phosphatase in the fish revealed no significant difference $(P>0.05)$ when compared with the control. $A$ significant $(P<0.05)$ high level of glucose was found in $T_{2}$ when compared with other treatments and the control while the lowest value was recorded in $\mathrm{T}_{1}$ (control diet). There was no significant increase $(P>0.05)$ in the level of serum protein when compared with the control (Table 4). The highest value was found in $T_{1}$ while the lowest was recorded in control group.

\section{Discussion}

The study has demonstrated that supplementation of turmeric powder in the feed of $C$. gariepinus at various inclusion levels can improve the haematological, biochemical parameters as well as the cellular immune system of the fish including the phagocytic cells.

Examination of blood and biochemical biomarkers are useful diagnostic tools used in evaluating the physiological status of fish (Banaee et al., 2011; Pandey et al., 2017) and also in assessing the effect of replacement of ingredient on fish health (Fagbenro et al., 2013; Fawole et al., 2016).

Increase in RBCs and WBCs counts noticed in the investigation for African catfish fed diets containing varying levels of turmeric powder when compared with the control suggested that turmeric powder elevated the haematological profile of the fish.

Also WBC function is majorly to battle against infectious diseases, safeguard the body against infiltration by foreign substances and distribute antibodies as well as immune response (Ajima et al., 2015). Increase in WBC of the fish fed diet incorporated with turmeric powder may be the immune-modulatory potential of the powder. Increase in WBCs count has been reported in Green terror (Andinocara rivulatus) fed diet incorporated with varying level of turmeric powder (Mooraki et al., 2019). Increase in WBC has been also reported in $C$. gariepinus juveniles fed ginger (Zingiber officinale) supplemented diets (Iheanacho et al., 2018) and in Wuchang Bream (Megalobrama amblycephala) fed diets supplemented with curcumin (Xia et al., 2015). Elevated WBCs as well as other immunological parameters are shown to be valuable prove of the health condition of fish (Kumar et al., 2013).

The blood indexes including $\mathrm{MCV}, \mathrm{MCH}$ and $\mathrm{MCHC}$ play an important part in the assessment of anaemic condition in fish as well as in most other animals and are suggestive of the erythrocyte significance and oxygencarrying potential of the blood in fish (Houston, 1997). We found increment in $\mathrm{MCV}$ and $\mathrm{MCH}$ level in fish fed diet supplemented with turmeric powder with no significant difference in $\mathrm{MCHC}$; indicating that the oxygen-carrying abilities of blood for different metabolic processes were not weakened. Similar to our report, Fawole et al. (2020) noticed increment in MCV and MCH in C. gariepinus fed diet supplemented with pawpaw seed and onion peel powder.

The differences noted between the dietary groups in $\mathrm{Hb}$ and PCV indicated the ability of the fish to utilize diets incorporated with turmeric powder without compromising the oxygen-carrying capacity to the premier organs of the fish.

Leucocyte differentials including neutrophils, lymphocytes, monocytes and basophils, eosinophils play important part in cellular immune responses and are valuable indicator of health status of fish (Emeish and Eldeen, 2016; Fazlolahzadeh et al., 2011; Jeney, 2017). No significant different found in the leukocyte differentials indicated that supplementation of turmeric powder in the diet of $C$. gariepinus may not pose any toxic impasse on the fish. In comparison to our report, Iheanacho et al. (2018) reported non-significant difference in leukocyte differentials in C. gariepinus fed diet supplements of $Z$. officinale.

Increase in levels of SGPT/ALT, SGOT/AST and ALP in fish have been related to liver dysfunction or swelling which results in releasing these enzymes into the bloodstream through leakages (Akrami et al., 2015; Fawole et al., 2016; Ajima et al., 2019). In fact, these catalysts give an idea on the status of the liver and to know whether the fish fed with supplemented diets can cause hepatoxicity or damage to the liver cells.

We found in this study that the reactions of the above enzymes were significantly reduced in the feed dietary supplement of turmeric powder when compared with the control indicating that the inclusion of the powder did not elicit any hepatic dysfunction to the fish. In line with our findings, Shalaby et al. (2006) documented that the reactions of SGPT/ALT and SGOT/AST was reduced significantly with increment in the level of Allium sativum in Oreochromis niloticus and also in $M$. amblycephala that were fed diets supplemented with curcumin (Xia et al., 2015). Curcumin can improve the liver functions through stimulation and regeneration of liver cells as well as protecting the liver cells from the toxic compounds (Dewi et al., 2018).

Cholesterol plays a vital role in assimilation of fatty acids from the intestine and in their subsequent transport in the blood or haemolymph. Reduction in level of cholesterol in our study is in line with AbdelTawwab et al. (2018) who reported decreased level of serum cholesterol levels with elevated Ocimum gratissimum leaf extract in the feed of $C$. gariepinus. Hypocholesterolaemia has also been reported in Japanese flounder (Paralichthys olivaceus) fed diet Chlorella ellipsoidea supplementation (Kim et al., 2002), in Huso huso fed diet containing varying levels of Allium cepa (Akrami et al., 2015) and also in C. gariepinus fed diet supplemented with pawpaw seed and onion peel powder (Fawole et al., 2020).

Hyperglycaemic differences found in this study could be a change in metabolism of carbohydrate which elevated glucose-6-phosphatase reaction in the liver or 
triggered the rate of glycogen breakdown to meet energy requirement of the fish (Ajima et al., 2015). Increment in level of glucose in dietary supplementation with plant extract/powder has been reported (Saeidi et al., 2017; Abdel-Tawwab, 2015). Also, increased level of glucose was found in Carassius auratus fed diet supplemented with sugar beet leave extracts (Inanan and Acar, 2019).

The no significant increase in the level of serum protein found in this study could be attributed to the elevation of non-specific immune responses in fish (Abdel-Tawwab et al., 2018). Increase in serum protein has been reported in rainbow trout fed diet incorporated with stinging nettle (Urtica dioica) (Saeidi et al., 2017) and in C. auratus fed dietary Ferula elaeochytris root powder (Inanan et al., 2021). The result of both creatinine and urea levels in the fish indicated no significant difference between the control and those fed dietary supplement of turmeric powder indicating that inclusion of turmeric powder in the diet has no effect in the kidney function of the fish. Decrease in the level of creatinine in $C$. gariepinus fed diet incorporated with $Z$. officinale has been reported (Olaniyi et al., 2020).

\section{Conclusion}

The study demonstrated that inclusion of turmeric powder in the diet of $C$. gariepinus improved the haematological parameters by increasing the white blood cell of the fish; reduced the activities of some liver function enzymes including SGPT/ALT, SGOT/AST and $A L P$, improved the immune response of the fish by increasing the level of serum protein. The result further showed that turmeric powder can be used as a feed additive in the diet of $C$. gariepinus at $1 \%$ inclusion without any adverse effect on the physiological function of the fish because of the better results compared with other inclusions levels.

\section{Ethical Statement}

This research was conducted in accordance with the recommendations in the Guide for the Care and use of Laboratory Animals of Abia state University, Umuahia campus, Abia state, Nigeria. The protocol was approved by the Committee on the Ethics of Animal Experiments of the University.

\section{Funding Information}

No funding was received for the study.

\section{Author Contribution}

All the authors contributed equally in carrying out the study and drafting the manuscript.

\section{Conflict of Interest}

No conflict of interest.

\section{Acknowledgements}

The authors thank Department of Animal Science and Fisheries, Faculty of Agriculture, Abia State University, Umuahia Campus, Abia State, Nigeria for proving the equipment and other materials used for the study.

\section{References}

Abdel-Tawwab, M., Adeshina, I., Jenyo-Oni, A., Ajani, E.K., \& Emikpe, B.O. (2018). Growth, physiological, antioxidants, and immune response of African catfish, Clarias gariepinus (B.), to dietary clove basil, Ocimum gratissimum, leaf extract and its susceptibility to Listeria monocytogenes infection, Fish and Shellfish Immunology doi: 10.1016/j.fsi.2018.04.057.

Abdel-Tawwab, M. (2015). The use of American ginseng (Panax quinquefolium) in practical diets for Nile tilapia (Oreochromis niloticus): Resistance to waterborne copper toxicity, Aquaculture Research, 46, 1001-1006.

Ajima, M.N.O., Ogo, O.A., Audu, B. S., \& Ugwoegbu, K.C. (2015). Chronic diclofenac (DCF) exposure alters both enzymatic and haematological profile of African catfish, Clarias gariepinus. Drug and Chemical Toxicology, 38(4), 383-390.

Ajima, M.N.O., Pandey, P.K., Kumar, K., Poojary, N., \& Gora, A.H. (2019). Verapamil caused biochemical alteration, DNA damage and expression of hepatic stress-related gene biomarkers in Nile tilapia, Oreochromis niloticus. Comparative Clinical Pathology, 29 (1), 135-144.

Akrami, R., Gharaei, A., Mansour, M.R., \& Galeshi, A. (2015). Effects of dietary onion (Allium cepa) powder on growth, innate immune response and hemato-biochemical parameters of beluga (Huso huso Linnaeus, 1754) juvenile. Fish and Shellfish Immunology, 45(2), 828-834.

Allain, C.C. Poon, L.S. Chan, C.S.G. Richmond, W., \& Fu, P.C (1974). Enzymatic determination of total serum cholesterol. Clinical Chemistry, 20, 470-475.

Anderson, D.P. (2003). Text book of fish immunology. New Delhi, India: Narendra Publishing House, 177.

AOAC (Association of Official Analytical Chemists) (2005). Official Methods of Analysis of the Association of Official Analytical Chemists International (18th ed.). Gaithersburg, USA: AOAC International.

APHA (American Public Health Association) (2005). Standard Methods of Examination of Water and Wastewater, $21^{\text {st }}$ edition APHA, Washington, DC, 20001-23710.

Arciuli, M., Fiocco, D., Fontana, S., Arena, M.P., Frassanito, M.A., \& Gallone, A. (2017). Administration of a polyphenol-enriched feed to farmed sea bass (Dicentrarchus labrax L.): Kidney melanomacrophages response. Fish and Shellfish Immunology, 68, 404-410.

Arulkumar, A., Miranda, J.M., Ramanchandran, K., Paramasivam, S., \& Palanive R. (2017) Effects of turmeric (Curcuma longa) on shelf life extension and biogenic amine control of cuttlefish (Sepia brevimana) during chilled storage. Cyta - Journal of Food 15 (3), 441-447. https://doi.org/10.1080/19476337.2017.1296495 
Banaee, M., Sureda, A., Mirvaghefi., A., \& Ahmadi, K. (2011). Effects of diazinon on biochemical parameters of blood in rainbow trout (Oncorhynchus mykiss). Pesticide, Biochemistry and Physiology 99, 1-6.

Blaxhall, P.C., \& Daisely, K.W. (1973). Routine hematological methods for use with fish blood. Journal of Fish Biology, 5,771-781.

Bradford, M.M. (1976). Rapid and sensitive method for quantitation of microgram quantities of protein utilizing principle of protein dye binding. Annals of Biochemistry, 72,248-254.

Chan, E.W.C., Lim, Y.Y., Wong, S.K., Lim, K.K., Tan, S.P., Lianto, F.S., \& Yong, M.Y. (2009). Effects of different drying methods on the antioxidant properties of leaves and tea of ginger species. Food Chemistry, 113 (1), 166-172.

Cooper, G.R., \& McDaniel, V. (1970). Estimation of biochemical parameters. In: McDonald RP, ed. Standard Methods of Clinical Chemistry. New York: Academic Press, 162.

Coulombe, J.J., \& Favreau, L. (1963). A new simple semi micro method for colorimetric determination of urea. Clinical Chemistry, 9, 102-108.

Daneshyar, M., Alizadeh Ghandkanlo, M., Sabzi Bayeghra, F., Farhangpajhoh, F., \& Aghaei, M. (2011). Effects of dietary turmeric supplementation on plasma lipoproteins, meat quality and fatty acid composition in broilers. South African Journal of Animal Science, 41, 420-428.

Dewi, C.D., Manalu, W., Ekastuti D.R, \& Sudrajat A.O. (2018). The Role of Turmeric Powder Supplementation in Improving Liver Performances to Support the Production of Siam Catfish (Pangasianodon hypophthalmus). OmniAkuatika, 14 (1), 44-53.

Dewi, C.D., Manalu, W., Ekastuti D.R., \& Sudrajat A.O. (2020). The role of turmeric (Curcuma longa) powder in improving liver function to increase Vitellogenin synthesis and deposition in the Oocytes of Catfish (Pangasianodon hypophthalmus). Jordan Journal of Biological Sciences, 13(3), $357-362$

Emeish, W.F., \& El-deen, A.G. (2016). Immunomodulatory effects of thyme and fenugreek in sharptooth catfish. Clarias gariepinus. Assiut Veterinary Medical Journal, 62(150), 1-7.

Essey, O.A., Lowky, O.H., \& Brock, M.J. (1946). A method for the rapid determination of alkaline phosphatase with five cubic millimetres of serum. Journal of Biology and Chemistry, 164,321-329.

Fagbenro, O.A., Adeparusi, E., \& Jimoh, W.A. (2013). Haematological profile of blood of

African catfish (Clarias gariepinus, Burchell, 1822) fed sunflower and sesame meal based diets. Journal of Fisheries and Aquatic Science, 8(1), 80-86.

Fawole, F.J., Sahu, N.P., Pal, A.K., \& Ravindran, A. (2016). Haemato-immunological response of Labeo rohita (Hamilton) fingerlings fed leaf extracts and challenged by Aeromonas hydrophila. Aquaculture Research, 4, 37883799.

Fawole, F.J., Adeoye, A.A., Tiamiyu, L.O., Samuel, F.C., Omosuyi, O.M., \& Amusa, M.T. (2020). Dietary combination of pawpaw seed and onion peel powder: Impact on growth, haematology, biochemical and antioxidant status of Clarias gariepinus. Aquaculture Research, 00:1-10

Fazlolahzadeh, F., Keramati, K., Nazifi, S., Shirian, S., \& Seifi, S. (2011). Effect of garlic (Allium sativum) on hematological parameters and plasma activities of ALT and AST of
Rainbow trout in temperature stress. Australian Journal of Basic and Applied Sciences, 5(9), 84-90.

Gandhi, P., Khan, Z., \& Chakraverty, N. (2011). Soluble curcumin: a promising oral supplement for health management. Journal of Applied Pharmacy and Science 1(2), 1-7.

Henry, J.B. (1974). Clinical Diagnosis and Management, $17^{\text {th }}$ ed. W.B. Saunders, Philadelphia.

Houston, A.H. (1997) Review: Are the classical haematological variables acceptable indicators of fish? Transaction of American Fisheries Society, 126,879-894.

Iheanacho, S.C., Ogbu, M., Ude, E., Ayotunde, E., \& Ogueji, E. (2018). Growth, haematology and immuno-modulatory potential of ginger (Zingiber officinale) supplemented diets in Clarias gariepinus Juvenile (Burchell, 1822). Aquaculture Studies, 18(5), 41-49.

Inanan, B.E., \& Acar, Ü. (2019). Evaluation of sugar beet leave extracts in goldfish (Carassius auratus) diets: Effects on blood and semen parameters Acta Aquatica Turcica, 15(4), 458-468.

Inanan B.E. Acar U., \& Inanan, T. (2021). Effects of dietary Ferula elaeochytris root powder concentrations on haematology, serum biochemical parameters, spermatozoa parameters, and oxidative status in tissues of males goldfish (Carassius auratus). Aquaculture, 544, 737087.

Jahanbakhshi, A., Imanpoor, M.R., Taghizadeh, V., \& Shabani, A. (2013). Hematological and serum biochemical indices changes induced by replacing fish meal with plant protein (sesame oil cake and corn gluten) in the Great sturgeon (Huso huso). Comparative Clinical Pathology 22(6), 1087-1092.

Jeney, G. (2017). Fish diseases Prevention and Control Strategies. Academic press, London wall, 8p

Kim, K., Bai, S., Koo, J., Wang, X., \& Kim, S. (2002). Effects of dietary Chlorella ellipsoidea supplementation on growth, blood characteristics, and whole-body composition in juvenile Japanese flounder Paralichthys olivaceus. Journal of the World Aquaculture Society, 33, 425-431. https://doi.org/10.1111/j.1749-7345.2002.tb000 21.x

Kiron, V. (2012) Fish immune system and its nutritional modulation for preventive health care. Animal Feed Science Technology, 173,111-133.

Kolkovski, S., \& Kolkovski, J. (2011). Herbal medicine in aquaculture. International Aqua feed, 14(2), 28-31.

Kumar, S., Raman, R.P., Pandey, P.K., Mohanty, S., Kumar, A. \& Kumar, K. 2013. Effect of orally administered azadirachtin on non-specific immune parameters of goldfish Carassius auratus (Linn.1758) and resistance against Aeromonas hydrophila. Fish \& shellfish Immunology, 34, 564-573.

Landy, N., Ghalamkari, G.H., \& Toghyani, M. (2011). Performance, carcass characteristics and immunity in broiler chicks fed dietary neem (Azardirachta indica) as alternative for an antibiotic growth promoter. Livestock Science, 142(1), 305-309.

Lausen, K. (1972). Creatinine assay in the presence of protein with LKB 8600 Reaction Rate Analyser, Clinica Chinima Acta, 38, 475-476.

Magrone, T., Fontana, S., Laforgia, F., Dragone, T., Jirillo, E., \& Passantino, L. (2016). Administration of a polyphenolenriched feed to farmed sea bass (Dicentrarchus labrax L.) modulates intestinal and spleen immune responses. Oxidative Medicine and Cellular Longevity, 68, 1-11.

Mahmoud M.M.A., El-Lamie M M.M., Dessouki A.A., \& Yusuf 
M.S. (2014). Effect of Turmeric (Curcuma longa) supplementation on growth performance, feed utilization, and resistance of Nile tilapia (Oreochromis niloticus) to Pseudomonas fluorescens Challenge. Global Research Journal of Fishery Science and Aquaculture, 1(12), 026-033.

Mooraki, N., Batmany, Y., Zoriehzahram S.J., \& Kakoolaki, S.H. (2019). Evaluating the effect of using turmeric (Curcuma longa) on growth performance and hematological parameters of the ornamental fish, Green Terror (Andinocara rivulatus). Journal of Survey in Fisheries Sciences, 5(2), 37-47.

Nelson, D.A., \& Morris, M.W. (1989). Basic methodology, hematology and coagulation, Part IV. In: Nelson DA, Henry JB, eds. Clinical diagnosis and management by laboratory methods, 17th ed. Philadelphia (PA): W.B. Saunders, 578-625.

Olaniyi, C.O., Atoyebi, M.O., Obafunmiso, H.T., \& Salaam, K.A. (2020). Effect of ginger (Zingiber officinale) in the nutrition of African catfish- A cholesterol reducer and fertility enhancer. International Journal of Aquatic Fish Science, 6(2), 21-28. https://dx.doi.org/10.17352/24558400.000052

Pandey, P.K., Ajima, M.N.O., Kumar, K., Poojary, N., \& Kumar, S. (2017). Evaluation of DNA damage and physiological responses in Nile tilapia, Oreochromis niloticus (Linnaeus, 1758) exposed to sub-lethal diclofenac (DCF). Aquatic Toxicology, 186, 205-214.

Prasad, S., \& Aggarwal, B.B. (2011). Turmeric the golden spice from traditional medicine to modern medicine. Pages 263-288 in I.F.F Benzie and S. Wachtel-Galor, editors. Herbal medicine: Bimolecular and clinical aspects. $2^{\text {nd }}$ edition CRC press Taylor and Francis Group, Boca Raton, Florida USA

Reitman, S., \& Frankel, S. (1957). A colorimetric method for the determination of serum glutamic oxalo acetic and glutamic pyruvic transaminase. American Journal of Clinical Pathology, 766,28-56.

Ruby, A.J., Kuttan, G., Babu K.D., Rajasekharan, K.N., \& Kuttanm, R. (1995). Anti-tumor and antioxidant activity of natural curcumioids. Cancer Letters, 94, 79-83.
Rusia, V., \& Sood, S.K. (1992). Routine hematological tests. In: Mukerjee KL, ed. Medical laboratory technology. New Delhi: Tata McGrawHill, 252-258.

Saeidi, A.M.R., Adel, M., Caipang, C.M.A., \& Dawood, M.A.O. (2017). Immunological responses and disease resistance of rainbow trout (Oncorhynchus mykiss) juveniles following dietary administration of stinging nettle (Urtica dioica), Fish Shellfish Immunology, 71- 230-238.

Sahu, S., Das, B.K., Mishra, B.K., Pradhan, J., Samal, S.K., \& Sarangi, N. (2008). Effect of dietary Curcuma longa on enzymatic and immunological profiles of rohu, Labeo rohita (Ham.), infected with Aeromonas hydrophila. Aquaculture Research, 39, 1720-1730.

Sahu, S., Mishra, B.K., Pradhan, J., \& Das, B.K. (2005). Antibacterial activity of Curcuma longa on fish microbial pathogens. Journal of Aquaculture, 13, 9-16.

Sanchez, C.J.G., Velasco, R.R., \& Doctolero, J.S. (2019). Young turmeric (Curcuma longa) tuber as feed additive for the growth and survival of Nile tilapia (Oreochromis niloticus L.). International Journal of Fisheries and Aquatic Studies, 7(6), 181-184.

Shalaby, A.M., Khattab, Y.A., \& Abdel -Rahman, A.M. (2006). Effects of garlic (Allium sativum) and chloramphenicol on growth performance, physiological parameters and survival of Nile tilapia. Journal of Venomous Animal Toxins including Tropical Diseases, 12(2), 172-201.

Tayyem, R.F., Heath, D.D., Al-Delaimy, W.K., \& Cheryl, L. (2006). Curcumin content of turmeric and curry powders. Nutrition and Cancer, 55, 126-131.

Xia, S.L. Ge, X.P., Liu, B., Xie, J., Miao, L.H., Ren M.C., Zhou Q.L. Zhang W.X., Jiang X.J. Chen R.L., \& Pan L.K. (2015). Effects of Supplemented Dietary Curcumin on Growth and NonSpecific Immune Responses in Juvenile Wuchang Bream (Megalobrama amblycephala). The Israeli Journal of Aquaculture, 67, 1174

Yang, C., Chowdhur y, M.A.K., Hou, Y., \& Gong, J. (2015). Phytogenic compounds as alternatives to in-feed antibiotics: Potentials and challenges in application. Pathogens, 4(1), 137-156. 